\title{
RAD54L wt Allele
}

National Cancer Institute

\section{Source}

National Cancer Institute. RAD54L wt Allele. NCI Thesaurus. Code C51006.

Human RAD54L wild-type allele is located within 1 p32 and is approximately $31 \mathrm{~kb}$ in length. This allele, which encodes DNA repair and recombination protein RAD54-like protein, is involved in the homologous recombination related repair of DNA doublestrand breaks. 